\title{
Sähköinen liiketoiminta Suomen maatalous- ja elintarvikesektorilla
}

\author{
Ari Peltoniemi, Panu Kallio ja Juha Marttila \\ Pellervon taloudellinen tutkimuslaitos,Eerikinkatu 28,00180 Helsinki, ari.peltoniemi@ptt.fi
}

\begin{abstract}
Johdanto
Internetin käyttö lisääntyy maailmanlaajuisesti nopeaan tahtiin. Tietoverkkojen merkitys sekä yritysten välisessä tiedonsiirrossa että liiketoiminnan välineenä kasvaa tulevaisuudessa nykyistä huomattavasti suuremmaksi. Internetiä hyödynnetään yhä enemmän myytävien tuotteiden markkinoinnissa ja tuoteinformaatiossa. Sähköinen kaupankäynti muodostuu edelleen enimmäkseen yritysten välisestä kaupasta (B2B), mutta myös kuluttajille suunnatulla verkkokaupalla on kasvupotentiaalia.

Vuonna 2003 maailmanlaajuisen B2B-verkkokaupan arvo on arvioiden mukaan noin 3500 miljardia euroa, jossa on kasvua edellisestä vuodesta lähes $70 \%$. Ennusteen mukaan Euroopan Unionin alueella toimivien yritysten B2B-verkkokaupan arvo on vuonna 2003 noin 465 miljardia euroa eli vajaat $13 \%$ koko maailman B2B-verkkokaupasta (UNCTAD 2003).

Maatalous- ja elintarvikesektorin sähköinen liiketoiminta (eBusiness) on laaja käsite, johon voidaan laskea kaikki sähköisessä muodossa oleva informaatio ja kanssakäyminen, niin julkisen sektorin kuin yritystenkin. Sähköinen liiketoiminta voidaan ymmärtää tässä kolmiosaisena: kuluttajakauppa, yritysten välinen kauppa ja sisäisten prosessien tehostaminen. Sähköinen kaupankäynti (eCommerce) käsittää edellisen luokituksen kaksi ensimmäistä osa-aluetta. Nämä sisältävät myös verkkomarkkinoinnin ja viestinnän uudessa mediassa. Kolmas osa-alue, sisäisten prosessien tehostaminen, kattaa $\mathrm{mm}$. yritysten manuaalisten prosessien automatisoinnin sekä liikkeenjohtoa palvelevat tietojärjestelmät.
\end{abstract}

\section{Aineisto ja menetelmät}

Tämän tutkimuksen ensimmäisenä tavoitteena on selvittää sähköisen liiketoiminnan nykytila Suomen maa- ja elintarviketaloudessa. Kuinka laajoja ja millaisia elintarvikealan yritysten sähköisen kaupankäynnin palvelut ovat? Miten yritysten sisäiset tai eri yritysten väliset logistiikka-, informaatio-, ym. järjestelmät ovat muuttuneet? Toiseksi tutkimuksen tavoitteena on tutkia maatalousja elintarvikeyritysten sähköisen liiketoiminnan strategiaa ja tulevaisuutta.

Elintarvikesektorin sähköisen liiketoiminnan mahdollisia kehityskulkuja elintarvikeketjuun ja markkinoihin kartoitetaan kirjallisuuden ja kyselytutkimuksen avulla. Lisäksi eri yritysten asiantuntijoille tehdyillä henkilöhaastatteluilla on kerätty tietoa uuden teknologian mukanaan tuomista mahdollisuuksista ja tulevan kehityksen suuntaviivoista elintarviketaloudessa.

Vuoden 2003 kevään aikana PTT teki kyselyn suomalaisille maatalous- ja elintarvikealan yrityksille. Sähköpostin liitetiedostona lähetetyn kyselyn avulla kartoitettiin sähköisen liiketoiminnan ja kaupankäynnin hyödyntämisen laajuutta tutkimukseen osallistuneissa yrityksissä sekä yritysten näkemyksiä tulevaisuuden kehityssuunnista. Sähköisen kaupankäynnin analyysi keskittyy yritysten väliseen kauppaan, jossa myös suurimmat investointipanostukset ja kauppavolyymit on tehty. UNCTAD (2002) arvioi, että noin $95 \%$ maailman sähköisestä kaupankäynnistä on peräisin yritysten keskenään käymästä kaupasta.

\section{Tulokset ja tulosten tarkastelu}

Boehljen ym. (2000) tutkimuksen mukaan kolme neljästä Yhdysvaltain maatalous- ja elintarvikesektorilla toimivasta yrityksestä pitää luottamuksellisen asiakassuhteen kehittämistä sähköisen kaupankäynnin välineillä vaikeana tai hyvin vaikeana. Tutkimuksessa käy lisäksi ilmi, että puolet vastanneista yrityksistä ennakoi liiketoiminnan sähköistymisen parantavan tulevaisuudessa varastonhallintaa, mutta vastaavasti tuotteiden jakeluun liittyvien ongelmien nähtiin rajoittavan sähköisen kaupankäynnin kasvuvauhtia.

Maataloustuotteiden kaupan monimutkainen ja henkilökohtainen luonne lähtöisin olevat syyt hidastaa niiden B2B-verkkokaupan kehitystä. Toisaalta se avaa myös mahdollisuuksia mm. yksityiskohtaisen tuoteinformaation keräämisen, yksilöllisen asiakasrekisterin ylläpitämisen ja tuotedifferentioinnin kautta.

Yhteensä 56 kyselylomaketta lähetettiin sähköpostin liitetiedostona PTT:n kyselyssä. Vastauksia palautui 35, joten noin 63 prosenttia kyselylomakkeen saaneista osallistui kyselyyn. Vastaajat arvioivat muun muassa, että tähän mennessä heidän työmääränsä ja sitä kautta myös 
kustannukset ovat vähentyneet sähköisen kaupankäynnin myötä varsinkin tilausten käsittelyssä (taulukko 1). Myös myyntityössä työt ja kustannukset olivat yleensä vähentyneet, mutta kuljetuksissa ja varastotoiminnoissa sähköinen kaupankäynti ei ollut pääosan vastaajista mielestä saanut aikaan muutosta. Toimialakohtaisesti tarkasteltuna voidaan todeta, että hiukan yllättäen sähköisen kaupankäynnin vaikutukset työmäärän ja kustannusten vähentämiseen olivat maatalouden panostuottajien kohdalla pienemmät kuin elintarviketeollisuudessa ja kaupan alalla. Tähän vaikuttaa osaltaan se, että vaikka rehujen kaltaiset massatuotteet soveltuvat sähköiseen kaupankäyntiin hyvin, maataloustuottajat arvostavat edelleen niiden kaupan sinetöinnissä henkilökohtaista kontaktia myyjän kanssa.

Taulukko 1. Sähköisen kaupankäynnin vaikutukset yrityksien työmääriin/kustannuksiin seuraavissa toiminnoissa.

\begin{tabular}{|c|c|c|c|c|c|c|}
\hline & Vähentynyt & Vähentynyt & Ei muutosta & Kasvanut & Kasvanut & \multirow[b]{2}{*}{$\mathrm{N}$} \\
\hline & selvästi & hiukan & & hiukan & selvästi & \\
\hline Myynti & 8 & $\begin{array}{r}17 \\
\end{array}$ & 7 & \begin{tabular}{|l}
2 \\
\end{tabular} & 0 & 34 \\
\hline Kuljetukset & 1 & 12 & 21 & 0 & 0 & 34 \\
\hline Varastointi & 3 & 10 & 19 & 1 & 0 & 33 \\
\hline Tilausten käsittely & 16 & 11 & 5 & 2 & 0 & 34 \\
\hline
\end{tabular}

Mitä suurempi yritys sitä yleisempää sähköinen kaupankäynti on myynnissä. Ostoissa yrityksen koko ei juurikaan korreloinut verkkokaupan käyttötiheyden kanssa. Yritykset käyttävät ostotapahtumassa verkkokauppaa huomattavasti vähemmän kuin myyntitapahtumissa. Lähes $70 \%$ yrityksistä soveltaa sähköistä kaupankäyntiä alle 10 prosenttiin ostoistaan. Sähköisen kaupankäynnin painottumista myyntiin selittää ainakin osittain tilaustenkäsittelyn ja asiakasrekisterin ylläpidon helpottuminen verkkokaupan avulla.

Kyselyyn osallistuneilta henkilöiltä pyydettiin arviota seuraaviin kolmeen väittämään: a) Sähköinen kaupankäynti syrjäyttää tulevaisuudessa nykymuotoisen monikanavaisen (perinteinen myymälä \& sähköinen kauppa) kaupan? b) Yrityksenne verkkokaupan arvo vähintään kolminkertaistuu seuraavan viiden vuoden aikana? c) Internet-huutokauppojen merkitys kasvaa toimialallanne merkittävästi seuraavan viiden vuoden aikana?

Kuvio 1. Sähköisen kaupankäynnin tulevaisuudennäkymät.

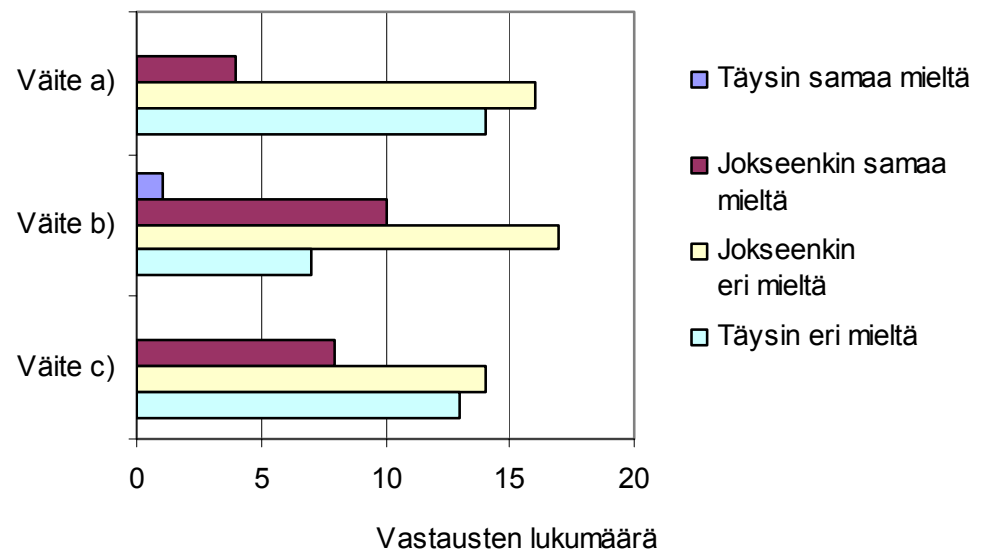

Sähköisen kaupankäynnin tulevaisuuden näkymiä kartoittaviin väittämiin annettujen vastausten perusteella sähköisen kaupankäynnin ei juurikaan odoteta vievän nykymuotoisen kaupankäyntitavan hallitsevaa asemaa ainakaan kokonaisuudessaan. Suurta nousua verkkokaupan kasvussa ei pidetä todennäköisenä, sillä vain kolmannes vastaajista piti edustamansa yrityksen verkkokaupan kasvattamista kolminkertaiseksi seuraavan viiden vuoden aikana mahdollisena. Erityisesti Yhdysvalloissa paljon käytettyjen Internet-huutokauppojen ei uskota saavuttavan suurta jalansijaa Suomen maatalous- ja elintarvikesektorilla keskipitkällä aikavälillä (kuvio 1). 


\section{Johtopäätökset}

Sähköinen liiketoiminta otetaan lähes poikkeuksetta huomioon suomalaisten elintarvikeyritysten strategisessa suunnittelussa. Kuitenkin vain harvoilla yrityksillä on toistaiseksi erillinen sähköisen liiketoiminnan strategia, joten sähköinen liiketoiminta on yleensä yksi palanen yritysten kokonaisvaltaisessa liiketoimintastrategiassa.

Sähköisen liiketoiminnan hyödyt tulevat erityisesti esille suomalaisten elintarvikealan yritysten toiminnanohjauksessa. Integroiduilla raportointi- ja liiketoiminnan suunnittelujärjestelmillä nopeutetaan ja tarkennetaan toiminnan seurantaa, ohjaamista ja kehittämistä.

Kyselyyn vastanneiden mielestä sähköinen liiketoiminta mahdollistaa toimintojen ajan tasalla olevan seurannan ja edistää kaupankäyntiä. Useassa yrityksessä korostettiin mahdollisuutta reaaliaikaiseen tilausten ja toimitusten seurantaan. Uutena palveluna tulevat esille myös sähköiseen liiketoimintaan kehitetyt maksu- ja rahoitusinstrumentit. Lisäksi eräiden yritysten mielestä maatalouskoneiden huoltopalveluiden sähköistyminen tulee olemaan tulevaisuudessa merkittävä sähköisen liiketoiminnan luoma uusi palvelu.

Sähköisen kaupankäynnin odotetaan lisääntyvän tulevaisuudessa. Elintarviketeollisuus näkee suurimman kasvumahdollisuuden myynneissä hotelli-, ravintola- ja suurkeittiöasiakkaille. Maataloudelle panoksia valmistavat toimialat panostavat verkkopalveluihin tiivistääkseen ja tehostaakseen yhteistyötä sopimusasiakkaiden kanssa. Verkkokaupan kasvumahdollisuudet ovat suurimmat yksinkertaisissa massatuotteissa, kuten siemenet, lannoitteet, rehut, kasvinsuojeluaineet ja maatalouskoneiden varaosat. Näiden kohdalla kaupan rooli lisäarvoa tuottavana tekijänä voi kuitenkin vähentyä, sillä logistiset järjestelmät ohjataan yhä useammin suoraa väylää valmistajalta loppukäyttäjälle.

\section{Kirjallisuusluettelo}

UNCTAD 2002. E-Commerce and Development Report 2002. United Nations: New York \& Geneva.

UNCTAD 2003. E-Commerce and Development Report 2003. United Nations: New York \& Geneva.

Boehlje, M., Dooley, F., Akridge, J. \& Henderson, J. 2000. E-commerce and Evolving Distribution Channels in the Food and Agribusiness Industries. Paper presented at the IAMA Conference, 2000. 